\title{
Innovation-Driven Business Case of Hanuman Vitamin
}

\author{
H. M. Jha "Bidyarthi", , S. M. Mishra ${ }^{2}$, M. A. Dande' ${ }^{2}$ P. M. Kuchar ${ }^{2} \&$ A. K. Shrivastava ${ }^{3}$ \\ ${ }^{1}$ Professor and Head, Department of Business Administration and Research, Shri Sant Gajanan Maharaj College of \\ Engineering, Buldhana, Maharashtra, INDIA \\ ${ }^{2}$ Assistant Professor, Department of Business Administration and Research, Shri Sant Gajanan Maharaj College of \\ Engineering, Buldhana, Maharashtra, INDIA \\ ${ }^{3}$ Professor, Dean and Director, Institute of Management, Pt. Ravishankar Shukla University, Raipur, Chattisgarh, \\ INDIA
}

Correspondence: H. M. Jha "Bidyarthi", Professor and Head, Department of Business Administration and Research, Shri Sant Gajanan Maharaj College of Engineering, Shegaon 444203, Buldhana, Maharashtra, INDIA. E-mail hmjhabidyarthi@rediffmail.com; hmjhabidyarthi@ssgmce.ac.in

Received: November 6, 2019 Accepted: November 19, 2019 Online Published: November 25, 2019

doi:10.5430/jbar.v8n2p30

URL: https://doi.org/10.5430/jbar.v8n2p30

\begin{abstract}
The proverbial saying - "to have mango at the coronel's price" - fits exactly true in case of Hanuman Vitamin Foods Ltd., Khamgaon, a Public company established in the year 1966 which produced oil cake from the stone of the mango. This uniquely innovated venture went on to add production of Sal Seed oil, Kokum oil, Dhupa Seed oil, Illepe Nuts (from Indonesia) oil and Shea Nuts (from West African countries) oil through ultra modern plants/process manufacturing De Oiled Cake (DOC) and Cocoa Butter Equivalence (CBE) and exported them to Japan, Italy, Switzerland and all European countries except US. The company became number one Indian manufacturer and exporter of these products and grew in scale and expanded by setting up a new plant at Raipur in the State of Chattisgarh. However, in 2002 - 2003, Hanuman Vitamin Foods Ltd. had to apply to the then Board of Industrial and Financial Reconstruction (BIFR) - now National Company Law Tribunal (NCLT) - for being declared as sick unit and for obtaining government assistance under insolvency and bankruptcy code for its revival. And it finally stopped production in the year 2008 after which the financer banks took the possession of the company through Asset Management Company. The steep rise and fall of Hanuman Vitamin unfolds a host of significant management lessons in innovation and entrepreneurship.
\end{abstract}

Keywords: Innovation-driven business, entrepreneurship, indigenous quotient (IQ)

\section{Introduction}

It all started by producing cotton seed oil through traditional method of Kolhu Ki Ghani in the year 1930 by Shri Jankilal Agarwal who had moved from his native in Rajasthan to Khamgaon of Buldhana district in Maharashtra in search of business. Cotton seed oil was not used as edible oil then and by conceiving its production Shri Jankilal Agarwal had sown the seeds of indigenous business innovation which percolated to the subsequent generations of his family. It is almost a century of years now that his legacy of business innovation was carried forward by Hanuman group of industries. Hanuman Vitamin Foods Ltd., Khamgaon is a flagship company of this group which is a uniquely innovated venture started by his two sons and incorporated after the name of his second son Hanumandas as a Public company in the year 1966 (https://www.zaubacorp.com/company/HANUMAN-VITAMIN-FOODSLIMITED/U99999MH1966PLC013614) translating the proverbial saying - "to have mango at the coronel's price" into reality as this company produced oil and oil cake from the stone of the mango. The company grew in scale of operation, even expanded by setting up a new plant in neighboring State, became number one company in India in manufacture and export of De Oiled Cake and Cocoa Butter Equivalence through a series of indigenously developed business innovations. With the fast growth of the company grew some internal challenges and some external threats which finally saw the demise of this company. This case attempts to capture the journey of Hanuman Vitamin and related firms, its growth and expansion, those practices which caused its downfall and the possibilities that came its way to survive. 


\section{Indigenous Innovation in Business}

An entrepreneur shifts economic resources out of an area of lower into an area of higher productivity and greater yield, (Drucker, 1991) and this he does by starting his own, new and small business (Drucker, 1991). Enterpreneurs innovate. Innovation is the specific instrument of entrepreneurship (Drucker, 1991).

Business innovation is a process for introducing new ways, new ideas, workflows, methodologies, services or products to achieve goals of the organization (https://searchcio.techtarget.com/definition/business-innovation). It is for the leaders of the organization to consider the business viability, feasibility and desirability of introducing these new ways etc. that leads to some problem solution, revenue generation or value optimization. Hanuman Vitamin Foods Ltd. is a live case of business innovations mostly developed indigenously and its consequences. Innovation may sometimes end with an experienceof a 'let down' at the end of a project which is also called as 'post partum depression' (Gamez, 2003).

There are two types of business innovations (Jay Turo, 2018). They are revolutionary business innovations or radical business innovations which yield drastic change and the second one is evolutionary business innovation which passes through the test of time. Depending upon the success and failure of such business innovations its innovation quotient is measured in terms of the following two (Jay Turo, 2019):

"The first is discouraged energy: It is burnout, caused by the passage of time, by much hard work without ample rest, and by the attempting of very many new things that just didn't work out and produce as planned." And

"The second is unfocused energy: It is where a great "fighting spirit" is alive and well but is scattered, with multiple new initiatives being pursued at the same time, but without clear senses of prioritization or realistic time frames for their completion."

Some of the sources lie within the enterprise and they are therefore visible primarily to people within that enterprise. These sources are a) the unexpected success, the unexpected failure, the unexpected outside event; b) the incongruity between reality as it actually is and reality as it is assumed to be; c) innovation based on process need; and finally d) changes in industry and market structure that catch everyone unawares (Drucker, 1991). Indigenous quotient may be defined in terms of the degree or component of indigenous development and design of innovation. It would be seen in the following paragraphs that Hanuman Vitamin Foods Ltd. went in mostly for indigenous business innovations.

\section{Methodology of Study}

This paper is based on primary research. There were seven types of primary respondents who were interviewed for the purpose of developing this case. These respondents are listed as follows.

a) Promoter of Hanuman Vitamin Foods Ltd.

b) Relatives of promoter having worked in his company

c) Erstwhile employees of the company

d) Financing banks' representatives

e) Representatives of Asset Management Company

f) Erstwhile suppliers of the company

g) Erstwhile transporters of the company.

In addition some secondary sources including websites were also referred to for collecting information however their quantity was minimal.

This paper is an outcome primarily of a series of meetings and interactions with one of the Directors of Hanuman Vitamin Foods Ltd, Shri Premji Hanumandas Saraf. The authors pushed him down to his memory lanes to recollect the journey of the company which resulted in lots of facts and information coming out of him which were all captured by the authors to draft this paper. All these interactions took place at the venue of the company itself. Incidentally many old employees of this company used to come there to meet Shri Premji Hanumandas Saraf who eventually became another samples for data collection. In certain cases Shri Premji and his erstwhile employees would together answer the queries put up by the authors or they would sometimes cross verify their memories with each other to ensure correctness of facts and information. Some relatives of Shri Premji who had worked in the Hanuman Vitamin Foods Ltd. became another sample of respondents. Responses were also collected from erstwhile suppliers and transporters of this company who could be contacted on piece meal basis. The representatives of the banks which were financers to Hanuman Vitamin and the representative of Asset Management Company which took 
possession of the company under study after being declared sick were also approached for collecting data.

\title{
4. Family Tree
}

Shri Jankilal Agarwal is the founder of Hanuman group of industries at Khamgaon starting with the traditional Kolhu Ki Ghani cotton seed oil producing unit in 1930. He had two sons namely Shri Hanumandas Agarwal and Shri Nathmalji Agarwal. All his firms were started in the name of Hanumandas - his second son - and hemce Hanuman group of industries. Shri Hanumandas used to look after entire manufacturing work in all the firms at Khamgaon where as Shri Nathmalji Agarwal would look after exports and imports from Bombay. Shri Nathmalji Agarwal had one son and three daughters but his son did not join his business due to family reasons. Shri Hanumandas Agarwal was blessed with three sons namely Shri Premji Saraf, Shri Ramesh Agarwal and Shri Murli Agarwal. Shri Premji Saraf got associated with his father Shri Hanumandas Agarwal and looked after entire manufacturing work and commercial functions at Hanuman Vitamin Foods Ltd., Khamgaon, Shri Ramesh Agarwal initially looked after production at Khamgaon but later on independently looked after Hanuman Minors Oils Ltd, Raipur which he is doing even today however, the plant has stopped manufacturing and it only does job works, and the third son Shri Murli Agarwal got associated with Shri Nathmalji Agarwal and started looking after entire exports, imports and banking and financial transactions works for both the units at Khamgaon as well as Raipur. Thus the three generations of entrepreneurs from Shri Jankilal Agarwal's family, as shown in the chart 1 given below, got engaged with his business that grew in scale of operation by leaps and bound.

\section{Grand Father-}

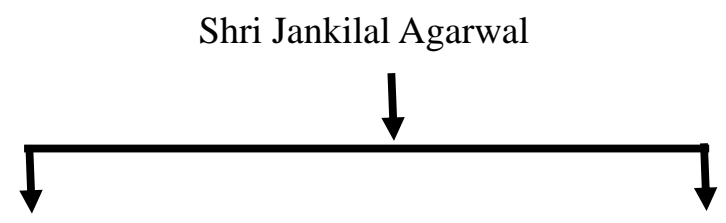

Sons-

Shri Nathmalji Agarwal

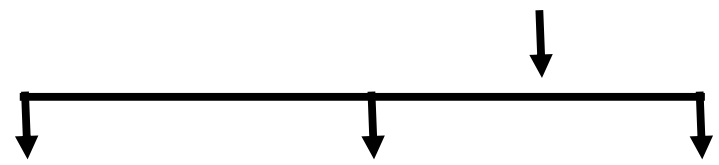

\section{Grandsons-}

\author{
Shri Premji Saraf Shri Ramesh Agarwal Shri Murli Agarwal
}

Chart 1. Showing Family Tree of Entrepreneurs

All the members of Shri Jankilal Agarwal's family had a clearly and categorically defined role in his business like any well structured organization.

\subsection{The Genius in Shri Nathmalji Agarwal}

Shri Nathmalji Agarwal was the elder son of Shri Jankilal Agarwal who was very highly educated and was a brilliant stuff by any standard. In 1940s, Nathmalji's education was B.Sc., M.Sc., L.L.B and then he went on to complete his B.E. in mechanical engineering from London. He was throughout - from B.Sc. onward - a gold medalist and he did his education from abroad through scholarships and not through family financing. After he came back from London he did not choose to accept employment of any organization which he could easily get then. He, instead, chose to join his father Shri Jankilal Agarwal in modernizing and developing his plant and business. He was a visionary man and people said that he always stood twenty years ahead of his time. He was a pure vegetarian and even though he travelled many countries about 50-60 years ago when vegetarian foods were rarely available on most of the foreign lands Nathmalji would live on milk and bread. He had spiritual bend of mind also and would always be companied by some spiritual guru with him. Towards the fag end of his life he settled at Puttuparthy, Bengaluru near by Satya Sai Baba who was live then and died at the age of 74 in the year 1992. But the innovations that he brought about are being implemented even today after about 25-30 years of his work. He would mostly look after the technological and other innovations in Hanuman Vitamin and at the same time would take care of its exports and imports from Bombay (now called as Mumbai). He was a voracious reader of literature where from he used to conceive innovations. He modernized cotton seed pressing unit, initiated production of high protein cotton seed oil cake through delinting, fiber and husks which were sold as cattle feeds, initiated production of cotton seed refined edible (first time in India) oil under Annapurna oil brand and popularized this edible oil in the region because the shelf life of materials fried in 
cotton seed edible oil was more than any other oil. He was thus a truly enterprising man.

\subsection{The Journey of the Firm}

Hanuman Vitamin Foods Ltd. was incorporated as the flagship company of Hanuman group of industries on seven acres of land in the year 1966 as obvious from the Chart No. 1 given below about milestones in the journey. It was a culmination of the traditional Kolhu Ki Ghani unit of cotton seed oil. The older generation of entrepreneurs focused primarily on traditional methods of oil extraction and also from traditional raw materials i.e. seeds like cotton seeds, Kardi, sunflower, Neem seeds and soybean. The second generation of entrepreneurs under the particular leadership of Shri Nathmalji Agarwal shifted from conventional oil extraction method to non-conventional and modern oil extraction method called as solvent extraction of oil from non-conventional oil seeds like mango stone (9\% oil content), Sal seed (14\% oil content), Kokum seed from western Maharashtra (40\% oil content with high melting character and hence a premium oil), Dhupa seed from Karnataka (20\% oil content), Illepe nuts from Indonesia and Shea nuts from West African countries (40-50\% oil content). Nathmalji Agarwal could know about these oil seeds through oil industries literature and his extensive tours to foreign countries. When he displayed his mango oil in one of the trade exhibitions in Germany it was so appreciated that the German media carried headlines stating "Gold lies in the streets of India".

The raw material base was also shifted from traditional farmer community to forest produce suppliers like lease contractors of forest produces. The plant was also modernized further from expeller plant to solvent plant where petroleum products used to be spread for extraction of oil from oil seeds and oil cakes. The processing was also modernized from press fractionation of oils to its solidification at lesser temperature and then hydraulically pressing to get products in liquid form called Oliene and solid form called Stearine. The finished products were also modernized from just being crude cotton seeds oil, to cotton seeds refined edible oil, to Staerine and Oliene, to Cocoa Butter Equivalence (CBE), to husk and fiber, to De Oiled Cake (DOC). The consumption end of the finished products were also diversified to local Vanaspati mills for sale of Oliene, to local market for use as cattle feed, to export markets like Italy, Japan, Switzerland and all European nations except United States for sale of CBE, to black soybean extraction (for the first time exported by any Indian firm then). Meanwhile a plant at Raipur was established in 1991 - 92 as subsidiary to Hanuman Vitamin Foods Ltd., Khamgaon on eight acres of land.

The supplies of raw materials used to be made through both rail as well as road transportation from all supply points including sea ports (for imported raw materials like Shea nuts from Western African countries and Illepe seeds from Indonesia). The rail supply accounted for 30-40\% of raw materials and the roadways accounted for the remaining $60-70 \%$ of raw materials. Mango stones and Sal seeds used to be purchased from Orissa, Bihar, Chattisgarh and Nepal boarder area. Other seeds were purchased from suppliers, government tenders (particularly of forest produces), from trade centers at big cities. The daily consumption of raw materials was 60 to 200 tons of seeds and 100 to 250 tons of oil cakes. Hanuman Vitamin employed 60-70 office staff and 300-400 skilled and unskilled labors. Such was the magnitude of operation of Hanuman Vitamin Foods Ltd. that it achieved an annual sales turnover of Rs. 70 Crores to Rs 120 Crores during the period 1970 to 2000 . The details of the journey of entrepreneurs under study have been shown in the table 1 given below.

Table 1. Showing Significant Milestones

\begin{tabular}{ll}
\hline Year & Milestones \\
\hline $\mathbf{1 9 3 0}$ & Setting up of Kolhu Ki Ghani Cotton Seed Oil Mill at Khamgaon \\
$\mathbf{1 9 3 5}$ & Installation of Electric Expelling System for extracting Cotton Seed Oil \\
$\mathbf{1 9 6 0}$ & $\begin{array}{l}\text { Hanuman Oil Mill was set up along with Cotton Seed De-linting and Decortications Plant for } \\
\text { producing high protein and low fiber cotton seed oil }\end{array}$ \\
$\mathbf{1 9 6 0}$ & Export of Cotton Seed Oil Cake began \\
$\mathbf{1 9 6 4}$ & $\begin{array}{l}\text { Cotton Seed Oil Cake was sent to Bombay for converting it into Cotton Seed De Oiled Cake } \\
\text { through job works by a plant there } \\
\mathbf{1 9 6 5}\end{array}$ \\
$\mathbf{1 9 6 6}$ & Hanuman Oil Mill was renamed as Hanuman Cotton Seeds Products Pvt. Ltd. \\
& Hanuman Vitamin Foods Ltd. to make protein out of Soybean De Oiled Cake and so named \\
\hline
\end{tabular}




\begin{tabular}{|c|c|}
\hline 1969 & Solvent Plant was erected at Khamgaon \\
\hline $1971-72$ & $\begin{array}{l}\text { Refined Cotton Seed Oil under brand name Annapurna Oil started being sold as first ever edible } \\
\text { cotton seed oil. Before this crude cotton seed oil used to be sold by this company }\end{array}$ \\
\hline 1980 & $\begin{array}{l}\text { Micelle Refining Plant based on indigenous and self-developed technology was set up to } \\
\text { produce mango oil with less loss compared to conventional refining }\end{array}$ \\
\hline $1980-81$ & Press Fractionation Machine was installed \\
\hline $1989-90$ & Press Fractionation Machine started operating \\
\hline $1991-92$ & $\begin{array}{l}\text { Plant at Raipur, Chattisgarh was set up, in the name and style of Hanuman Minor Oils Ltd., as a } \\
\text { subsidiary unit of Hanuman Vitamin Fooda Ltd. and as part of expansion program and in vicinity } \\
\text { of raw materials supply points (Forest produces) }\end{array}$ \\
\hline 1997 & $\begin{array}{l}\text { Hexane Fractionation Plant was set up in Khamgaon which was again an indigenously } \\
\text { self-developed technology }\end{array}$ \\
\hline 1997 on wards & Deodorizing System for tackling pesticides issue started \\
\hline $2002-03$ & Started heading towards closure \\
\hline
\end{tabular}

\section{Important events which shaped the journey of the enterprise:}

While Nathmalji Agarwal was on its way of incessant business innovations with indigenous touch a number of internal challenges and external threats erupted simultaneously into his business. Some of these events have been captured in table 2 showing chronology of important events.

Table 2. Showing Chronology of important events

\begin{tabular}{|c|c|}
\hline Years & Important Events \\
\hline $1973-74$ & $\begin{array}{l}\text { Gosypol - a substance harmful for cattle and banned in Europe was found in the cotton seed oil } \\
\text { cake of Hanuman Vitamin hence its export to Europe stopped and because European nations } \\
\text { except US were the major buyers the business suffered a great set back }\end{array}$ \\
\hline $1975-76$ & $\begin{array}{l}\text { Alternative raw material was searched and mango stone was found to be producing mango oil } \\
\text { cake with high protein and low fiber }\end{array}$ \\
\hline 1976 & $\begin{array}{l}\text { Mango oil was kept in an exhibition in Germany. It was so much appreciated that the German } \\
\text { media carried headlines, "Gold lies in the Streets of India." }\end{array}$ \\
\hline 1980 & $\begin{array}{l}\text { Nestle India Ltd. Carried out a survey of Hanuman Vitamin for 2-3 months for a possible } \\
\text { collaboration which did not strike }\end{array}$ \\
\hline 1990 & $\begin{array}{l}\text { Ferrero Rocher - an Italian company attempted to collaborate with Hanuman Vitamin but the } \\
\text { same did not materialize because of logistical limitations at Khamgaon }\end{array}$ \\
\hline $1997-98$ & $\begin{array}{l}\text { Excessive pesticides found in the products resulting into return of a consignment of } 600 \text { tons of } \\
\text { products from Italy. The buyers became sensitive to pesticides content in the products and } \\
\text { rigorously checked for it. Unfortunately the products of the company did not conform to their } \\
\text { standards of below } 50 \mathrm{ppb} \text { pesticides and it had to go for additional cost incurring process for } \\
\text { removal of excessive pesticides through deodorizing. }\end{array}$ \\
\hline $1998-99$ & Bergad plant in Orissa was taken on lease which did not work properly \\
\hline $1999-2000$ & $\begin{array}{l}\text { Import of } 2000 \text { tons of Shea nuts from Western Africa without having installed supporting } \\
\text { technology. The oil remained in containers of transporters for a month and half and got rotten } \\
\text { such that it was later sold at value of soap than that of Cocoa Butter Equivalence incurring huge } \\
\text { loss. }\end{array}$ \\
\hline $2000-01$ & $\begin{array}{l}\text { Some investors were approached for infusing money into Hanuman Vitamin to bail it out from } \\
\text { bank's debt trap but that too did not work out. }\end{array}$ \\
\hline $2002-03$ & The Company applied to the then Board of Industrial and Financial \\
\hline
\end{tabular}


Reconstruction (BIFR) - now National Company Law Tribunal (NCLT) - for being declared as sick unit and for obtaining government assistance under insolvency and bankruptcy code for its revival.

$2007-08$

Production completely stopped and Banks took over the possession of the company through Asset Management Company

$2012-13$

Equipment and machineries of Hanuman Vitamin Foods Ltd. sold by the Asset Management Company as part of Bank's debt recovery plan

\section{Loopholes in the management of Hanuman Vitamin:}

Recalling back his perceptions about the possible reasons for the collapse of Hanuman Vitamin Foods Ltd., Premji Saraft, its Director, says that there were obvious lapses in the management of this company which were never noticed then. He presents these loopholes as follows:

i) Technology introduction without adequate home work: Technology like press fractionation was introduced into the business in the year 1980-81 but it remained idle for about 8-9 years before it became operational in the year 1988-89. This escalated cost of operation of the company besides making investment into development of this technology idle and non-productive for years together.

ii) Selection of wrong technology: The technology used was most of the times indigenously innovated and not established imported technology. For example Hexane fractionation plant was developed indigenously which did not work well causing cost escalation of the firm.

iii) Problem of excessive pesticides in oil produced from tree borne oil seeds (TBO): Detection of pesticides in raw materials in quantity more than the acceptable limit of $50 \mathrm{ppb}$ became another issue of concern. Deodorizing process was followed to bring down the level of pesticides to acceptable limit which became another cost center for the firm. Indigenously developing this deodorizing process also required a lot of money put into it.

iv) Logistical limitations of Khamgaon: Khamgaon is a place located neither near Bombay sea port for export - import access nor near any of the raw materials supplying States like Bihar, U.P., Chattisgarh, Orissa, Nepal boarders etc. This created a logistical limitation. It was for this reason that a plant in Raipur was set up which is in the State of Chattisgarh itself and nearer to Chattisgarh forests where from forest produces raw materials were supplied.

v) Seeds procured during rainy season from rain and flood affected States were of poor quality: It was also noticed that the raw seeds used to be spoiled due to excessive rains and flood situation in the states where from these seeds used to be procured.

vi) Too many innovations with very high indigenous quotient and at a very fast pace with no pilot testing: Mr. Nathmalji was a genius as already stated before. He was bubbling with innovations. Every now and then he would come out with an innovation primarily developed indigenously. He would be equally faster in implementing his innovation without any pilot trials. Eventually many innovations failed and all of these had incurred huge costs.

vii) Ambitious over-trading: The firm went in for over trading due to its high ambitions causing disruption in the market.

viii) Lack of professional management: Hanuman Vitamin Foods Ltd. was run through its own family members who had no exposure to professional skills of management. This by far became another reason of its collapse.

ix) Debts trap of banks: The losses of the company went on rising as a result of which it infused more fund in the business by taking additional loans in anticipation of arresting losses. Eventually losses were not arrested and debts mounted excessively resulting into fall of company in the banks debt trap. The firm thus became insolvent and bankrupt and had to seek government intervention to be declared as sick unit under BIFR.

\section{Conclusions}

The Hanuman Vitamin Foods Ltd. is a case of multiple and diversified products that ran in trouble in about 50 years 
of time. From being just a conventional method based small venture this company grew into a technology intensive highly innovative multinational company. Business innovations are tool of progressive organizations. But this statement appears not to be appropriating with the case of present organization. Rather too many innovations with very high indigenous quotient and at a very fast pace probably landed this organization in trouble. Though this case highlights some of the perceived lapses in the management of Hanuman Vitamin Foods Ltd. it requires a thorough case analysis to go to the root cause of the collapse of this company and more importantly to forward possible mechanism to bail out Hanuman Vitamin. This about a century old entrepreneurial outfit needs a Vitamin dose.

\section{References}

Business Innovation. Retrieved June 24, 2018, from https://searchcio.techtarget.com/definition/business-innovation

Drucker, P. F. (1991). Innovation and Entrepreneurship - Practice and Principle (pp. 30-35). Affiliated East West Pvt. Ltd., New Delhi.

George, G. (2003). Creativity - How to Catch Lightening in a Bottle (p. 202). Jaico Publishing House, Mumbai.

Hanuman Vitamin Foods Ltd. Retrieved 24 December, 2017, from https://www.zaubacorp.com/company/HANUMAN-VITAMIN-FOODS-LIMITED/U99999MH1966PLC01361 4

Jay Turo. (2018). Innovation Quotient. Retrieved June 24, 2018, from https://www.growthink.com/content/what-your-organizations-iq-innovation-quotient-0

Jay Turo. (2019). Are you a bad innovator?. Retrieved March 8, 2019, from https://www.growthink.com/content/what-your-organizations-iq-innovation-quotient-0

\section{Notes}

Kolhu Ki Ghani - A conventional method of extracting oil from seeds by putting them in a big wooden bowl called "Kolhu" in vernacular language and crushing it with heavy wooden block that is rotated in the bowl with the help of an ox.

$\mathrm{CBE}$ - Cocoa Butter Equivalence used as raw material in Chocolate production

DOC - De Oiled Cake

TBO - Tree Borne Seeds produced by forests

Deodorization - Minimizing pesticides contents from TBO

De-linting - A process to remove external shell - called lint - from cotton seeds by braking the seeds

Decortications - A process to get Coronel from de-linted cotton seeds

Expeller - A machine that squeezes oil from seeds by exerting physical pressure on it

$\mathrm{ppb}$ - Parts per billion

SEP - Solvent Extraction Plant

Hexane - A petroleum product spread on DOC to absorb remaining oil from it

Oliene - A liquid product used by Vanspati mills for producing vegetable oil

Stearine - A solid product exported for use in CBE which is subsequently used as raw material for manufacturing chocolates.

*The earlier version of this paper was presented at International Conference on Management Cases 2018 held at Birla Institute of Management Technology, Greater Noida, India during November 29 - 30, 2018 and the same was published in the proceedings of this conference. 